\title{
PENTINGNYA PENGETAHUAN DALAM PENCEGAHAN PENYAKIT AKIBAT KERJA PADA PERAWAT DI RUMAH SAKIT
}

\author{
Fitri Rahmadani Siregar \\ danisiregar1001@gmail.com
}

\section{Latar Belakang}

Rumah Sakit merupakan tempat kerja serta tempat berkumpulnya orang-orang sehat (petugas dan pengunjung) dan orang- orang sakit (pasien) sehingga rumah sakit merupakan tempat kerja yang mempunyai risiko tinggi terhadap penyakit akibat kerja maupun penyakit akibat kecelakaan kerja. Selain potensi bahaya berupa penyakit infeksi yang umumnya berasal dari pasien, rumah sakit juga mempunyai potensi bahaya lain yang mempengaruhi situasi dan kondisi di rumah sakit yaitu peledakan, kebakaran, kecelakaan yang berhubungan dengan instalasi listrik, radiasi, bahan - bahan kimia berbahaya, gas anestesi, gangguan psikososial, dan ergonomi (Aditama, 2006).

Pengetahuan perawat mengenai pencegahan infeksi dengan melakukan tindakan septik dan aseptik serta kemampuan untuk mencegah transmisi infeksi di rumah sakit adalah tindakan pertama dalam pemberian pelayanan yang bermutu. Hal ini dapat diupayakan melalui peningkatan sikap perawat tentang kesadaran menggunakan APD dalam melakukan setiap tindakan keperawatan. Perawat dalam memberikan pelayanan kesehatan kepada pasien harus mempunyai pengetahuan dan sikap yang baik tentang penggunaan APD dalam setiap pemberian pelayanan kesehatan pada pasien.

Menurut Notoatmodjo (2007) Pengetahuan merupakan hasil dari tahu dan terjadi setelah orang melakukan penginderaan terhadap suatu objek tertentu. Pengindraan meliputi penglihatan, pendengaran, penciuman, rasa dan raba. Pengetahuan merupakan bagian dari perilaku yang tidak bisa diamati secara langsung oleh orang lain karena masih terjadi didalam diri manusia itu sendiri (covert behavior). semakin tinggi tingkat pengetahuan seseorang maka akan tahu tentang tindakan yang harus dilakukannya dalam hal ini tindakan untuk mencegah terjadinya infeksi baik terhadap perawat itu sendiri maupun terhadap pasien. Dari hasil analisa univariat didapat bahwa perawat yang telah melakukan tindakan pencegahan infeksi yaitu 56,5\%. 
Frank menjelaskan, penyebab Penyakit Akibat Kerja (PAK) dan kecelakaan kerja disebabkan oleh manajemen kurang kontrol.Reason mengatakan orang tidak meng gunakan Alat Pelindung Diri (APD) diri dikar enakan kurang pengetahuan atau keterampilanya pekerja hal ini, disebabkan kurangnya pelatihan, prosedur atau peraturan mengenai keselamatan kerja. mengatakan bahwa penyebab kecelakaan kerja adalah ketimpangan manajemen sehingga memperlihatkan pengaruh manajemen dalam mengakibatkan terjadinya kecelakaan kerja. (Djatmiko, 2016)

\section{Metode}

Metode yang digunakan dalam penulisan ini adalah metode kualitatif yang mana mengumpulkan sebanyak-banyaknya data untuk dianalisis. Tulisan ini didasarkan dengan menganalisis berbagai karya penelitian yang berfokkus pada "Pengetahuan Dalam Pencegahan Penyakit Akibat Kerja Pada Perawat Di Rumah Sakit". Adapun tinjauan literature yang digunakan seperti buku, jurnal print maupun jurnal online dan e-book yang setiap referensi minimal 10 dengan tahun paling tua 2012. Penulisan ini juga menggunakan metode kajian bebas terhadap pokok bahasan yang dikumpulkan dari beberapa sumber yang berkaitan dengan pokok bahasan. Pengolahan ini dilakukan dengan metode membandingkan beberapa jurnal atau karya ilmiah lain yang berhubungan dengan pencegahan penyakit akibat kerja pada perawat.

\section{Hasil}

Hasil dari pengkajian menggunakan metode penulisan kualitatif menghasilkan suatu pembelajaran yaitu dapat mengetahui pengetahuan apa saja yang perlu diketahui oleh perawat dalam upaya pencegahan penyakit akibat kerja pada perawat dengan benar melalui pengumpulan data berdasarkan buku teks, jurnal atau karya tulis ilmiah. Diharapkan juga agar perawat mengetahui hal-hal terkait pencegahan penyakit akibat kerja pada perawat di rumah sakit.

Peran perawat dalam sebuah rumah sakit sangat penting karena perawat berinteraksi dan melakukan penanganan langsung dengan pasien. Tidak hanya banyak berinteraksi dengan pasien, perawat juga memiliki interaksi yang lama dengan keluarga pasien yang sedang dirawat. Pelayanan yang diberikan oleh perawat ini tentunya akan mempengaruhi citra rumah sakit tempat ia bekerja. Setiap hal yang dilakukan perawat juga akan berpengaruh pada kinerja dari rumah sakit tersebut. 
Perawat yang puas dengan apa yang diperoleh dari rumah sakit akan memberikan kontribusi dan akan terus memperbaiki kinerjanya. Hasil kinerja perawat dapat dilihat dari berbagai segi yang disebut Indikator Kinerja Utama (IKU) yang dilakukan oleh kepala bagian SDM. IKU digunakan untuk membantu rumah sakit mengetahui tingkat perkembangan dan merumuskan langkah kegiatan berikutnya. IKU dipakai dalam membuat arah tujuan, menentukan target, dan kerangka waktu. Penggunaan IKU dapat mempengaruhi penilaian terhadap perawat.

Perawat yang memiliki sikap baik akan memiliki perilaku yang baik pula karena sikap merupakan itikat dalam diri seseorang untuk dapat melakukan pekerjaan sebagai bagian dari aktivitas yang menyenangkan sehingga sanggup berperilaku sesuai dengan pengetahuan yang didapat. Perawat dengan pengetahuan yang baik akan memiliki tindakan K3 yang baik pula karena dengan tingkat pengetahuan yang baik mengetahui dan memahami dampak negatif dari infeksi nosokomial sehingga perawat akan meningkatkan kinerjanya dalam pengendalian infeksi.

\section{Pembahasan}

Pengetahuan adalah domain yang cukup penting dalam terbentuknya perilaku. Salah satu bentuk objek kesehatan seperti penggunaan alat pelindung diri (APD) di dapatkan dari pengalaman seperti mengikuti pelatihan, seminar atau workshop pentingnya penggunaan alat pelindung diri (APD). Penggunaaan Alat Pelindung Diri (APD) oleh perawat digunakan untuk mencegah terjadinya infeksi bagi perawat saat dimulainya tindakan kepada pasien. Tidak hanya bagi petugas kesehatan, tetapi juga bagi pengunjung yang dalam hal ini bagi yang mengunjungi pasien seperti TB paru yang mengharuskan pasien, petugas kesehatan, dan pengunjung menggunakan masker. Banyak faktor yang mempengaruhi penggunaan APD baik dari internal maupun eksternal.

Kejadian infeksi yang tinggi di rumah sakit merupakan indikator pentingnya suatu usaha pengendalian infeksi dengan menerapkan standar kewaspadaan infeksi (Standard precaution). Standard Precaution pada dasarnya merupakan transformasi dari universal precaution, yaitu suatu bentuk precaution pertama yang bertujuan untuk mencegah infeksi nosokomial (Kathryn, 2004). Dalam meningkatkan upaya tindakan pencegahan infeksi, diperlukan pengetahuan dan sikap perawat dalam penggunaan alat pelindung diri (APD) agar terhindar dari risiko penularan penyakit baik dari pasien ke perawat maupun sesama pasien. Perawat juga mempunyai risiko yang tinggi untuk menerima pajanan penyakit akibat adanya infeksi yang dapat mengancam keselamatannya saat berkerja. 
Perawat dalam memberikan pelayanan kesehatan kepada pasien harus mempunyai pengetahuan dan sikap yang baik tentang penggunaan APD dalam setiap pemberian pelayanan kesehatan pada pasien. mengingat fungsi APD memiliki peran yang penting dalam upaya mengeliminir transmisi agent penyakit infeksi baik dari lingkungan rumah sakit, dari pasien ke perawat maupun dari pasien ke pasien lainnya maupun infeksi yang terjadi pada pasien itu sendiri. Untuk dapat menggunakan APD secara benar harus didukung oleh pengetahuan dan sikap yang baik, dari segi pengetahuan perawat harus bisa memahami potensi risiko bahaya infeksi dan pintu masuk dari transmisi agent infeksi tersebut sehingga dapat memilih jenis dan bahan APD yang sesuai dengan potensi bahaya yang ada. Sedangkan dari segi sikap perawat harus didukung dengan perilaku yang baik terkait dengan penggunaan APD seperti kepatuhan dalam menggunakan APD dengan benar pada saat melakukan tindakan keperawatan dan kesadaran untuk merawat APD.

Pengetahuan merupakan hasil dari tahu dan terjadi setelah orang melakukan pengindraan terhadap suatu objek tertentu. Pengindraan meliputi penglihatan, pendengaran, penciuman, rasa dan raba. Pengetahuan merupakan bagian dari perilaku yang tidak bisa diamati secara langsung oleh orang lain karena masih terjadi didalam diri manusia itu sendiri (covert behavior). Pengetahuan yang tercakup dalam domain kognitif mempunyai 6 (enam) tingkatan (Notoadmodjo, 2007) .

1. Tahu (know) Tahu diartikan sebagai mengingatkan suatu materi yang telah dipelajari sebelumnya. Termasuk kedalam tingkat ini adalah mengingat kembali sesuatu yang spesifik dari seluruh bahan yang dipelajari atau rangsangan yang telah diterima. Oleh sebab itu tahu ini merupakan tingkat pengetahuan yang paling rendah. Kata kerja untuk mengukur bahwa orang tahu tentang apa yang dipelajari antara lain menyebutkan, menguraikan, mendefenisi kan, menyatakan dan sebagainya. 2. Memahami (comprehension) Memahami diartikan sebagai suatu kemampuan untuk menjelaskan secara benar tentang objek yang diketahui dan dapat menginterfrestasikan materi tersebut secara benar. Orang yang paham terhadap objek atau materi harus dapat menjelaskan, menyebutkan contoh, menyimpulkan, meramalkan dan sebagainya terhadap objek yang dipelajari. 3. Aplikasi (aplication) Aplikasi diartikan sebagai kemampuan untuk menggunakan materi yang telah dipelajari pada situasi atau kondisi yang sebenarnya. Aplikasi disini dapat diartikan sebagai penggunaan hukum-hukum, rumus, metode, prinsip dan sebagainya dalam konteks atau situasi yang lain. 4. Analisis (analysis) Analisis adalah suatu kemampuan untuk menjabarkan materi atau suatu objek kedalam komponen-komponen, tetapi masih dalam struktur organisasi, dan masih ada kaitannya satu 
sama lain. Misalnya mampu membedakan, memisahkan, mengkelompokan dan sebagainya. 5. Sintesis (synthesis) Sintesis menunjukan kepada suatu kemampuan untuk meletakan atau menghubungkan bagian-bagian dalam suatu bentuk keseluruhan yang baru. Dengan kata lain sintesis adalah suatu kemampuan untuk menyusun formasi baru dari formulasiformulasi yang ada. Misalnya dapat menyusun, merencanakan, meringkaskan menyesuaikan dan sebagainya terhadap suatu teori atau rumusan-rumusan yang telah ada.

6. Evaluasi (evaluation) Evaluasi ini berkaitan dengan kemampuan untuk melakukan penilaian terhadap suatu materi atau objek. Penilaian-penilaian itu berdasarkan suatu kriteria yang ditentukan sendiri atau menggunakan kriteria-kriteria yang telah ada. Misalnya, dapat membedakan antara anak yang gizi baik dengan gizi kurang.

Menurut Tietjen dkk (2004), Sebagian besar infeksi ini dapat dicegah dengan strategi yang telah tersedia secara relatif murah, yaitu : a. Mentaati praktek pencegahan infeksi yang dianjurkan, terutama kebersihan dan kesehatan tangan serta pemakaian sarung tangan, b. Memperhatikan dengan seksama proses yang telah terbukti bermanfaat untuk dekontaminasi dan pencucian peralatan dan benda lain yang kotor, diikuti dengan sterilisasi atau disinfeksi tingkat tinggi; dan c. Meningkatkan keamanan dalam ruang operasi dan area beresiko tinggi lainnya dimana kecelakaan perlukaan yang sangat serius dan paparan pada agen penyebab infeksi sering terjadi. Tidak semua infeksi nosokomial dapat dicegah. Contohnya, beberapa merupakan pengaruh bertambahnya usia, penyakit kronis seperti diabetes yang tidak terkontrol, penyakit ginjal berat, kekurangan gizi berat, perawatan dengan obat-obatan tertentu (separti antimikrobia, kortikosteroid, dan agen-agen lain yang dapat menurunkan imunisasi), bertambahnya dampak AIDS (misalnya, infeksi oportunistik) dan radiasi. Tietjen dkk (2004).

Pada tahun 1995 Center of disease control and prevention (CDC) menetapkan bentuk pencegahaan: tindakan pencegahaan standart, didesain untuk semua perawatan pasien dirumah sakit tanpa memperhatikan diagnosa mereka atau status infeksi sebelumnya. Tindakan pencegahan transmisi, yang dibagi dalam katergori udara, doplet dan kontak dan digunakan pada pasien yang diketahui atau dicurigai terinfeksi atau terkolonisasi patogen secara epidemiologis dapat ditularkan melalui udara dan kontak. Tindakan pencegahan standart diterapkan untuk darah, sekresi,dan cairan tubuh tanpa memperhatikan apakah mengandung darah yang terlihat dan membran mukosa. Tindakan pencegahan berdasarkan transmisi dirancang untuk pasien yang telah didokumentasikan mengalami atau dicurigai 
terinfeksi yang dapat ditransmisikan melalui udara atau droplet, organisme yang secara epidemiologi, termasuk isolasi penyakit menular (Swearing, 2000).

Menurut Kepmenkes RI No.1239 tahun 2001 tentang Registrasi dan Praktek Perawat, perawat adalah seseorang yang telah lulus pendidikan perawat, baik di dalam maupun di luar negeri sesuai dengan ketentuan peraturan perundanganundangan yang berlaku. Menurut Kusnanto (2004) dalam melaksanakan praktek keperawatan, perawat juga dituntut melakukan peran dan fungsi sebagaimana yang diharapkan oleh profesi dan masyarakat sebagai pengguna jasa pelayanan keperawatan. Menurut Kusnanto (2004) peran merupakan tingkah laku yang diharapkan oleh orang lain terhadap seseorang, sesuai kedudukannya dalam suatu system.

Dalam Undang-Undang Nomor 36 Tahun 2009 tentang Kesehatan, Pasal 165 : pengelola tempat kerja wajib melakukan segala bentuk upaya kesehatan melalui upaya pencegahan, peningkatan, pengobatan, dan pemulihan bagi tenaga kerja. Berdasarkan pasal tersebut maka pengelola tempat kerja di Rumah Sakit mempunyai kewajiban untuk menyehatkan para tenaga kerjanya. Salah satunya adalah melalui upaya kesehatan kerja disamping keselamatan kerja. Rumah Sakit harus menjamin kesehatan dan keselamatan baik terhadap pasien, penyedia layanan atau pekerja maupun masyarakat sekitar dari berbagai potensi bahaya di Rumah Sakit. Oleh karena itu, Rumah Sakit dituntut untuk melaksanakan Upaya Kesehatan dan Keselamatan Kerja (K3) yang dilaksanakan secara terintegrasi dan menyeluruh sehingga risiko terjadinya Penyakit Akibat Kerja (PAK) dan Kecelakaan Akibat Kerja (KAK) di Rumah Sakit dapat dihindari. Penyakit akibat kerja di rumah sakit dapat menyerang semua tenaga kerja baik medis maupun non medis (Anies, 2005). Sehingga sasaran utama K3RS adalah tenaga medis, tenaga non medis, pasien, pengunjung / pengantar pasien, serta masyarakat sekitar Rumah Sakit.

\section{Kesimpulan \& Saran}

Pelatihan merupakan proses mengajarkan pengetahuan, keahlian tertentu dan sikap agar perawat semakin terampil dan mampu melaksanakan tanggung jawab sesuai dengan standar. Perawat dengan pengetahuan yang baik akan memiliki tindakan K3 yang baik pula karena dengan tingkat pengetahuan yang baik mengetahui dan memahami dampak negatif dari infeksi penyakit sehingga perawat akan meningkatkan kinerjanya dalam pengendalian infeksi penyakit. Agar selalu memperhatikan faktor-faktor yang menjadi risiko timbulnya penyakit akibat kerja dan Selalu memperhatikan aturan dan tata cara setiap melakukan pekerjaan serta 
melaksanakan pelatihan secara rutin yang berkaitan dengan upaya-upaya pencegahan infeksi di rumah sakit.

\section{Daftar Pustaka}

Dita, F. N., \& Anis, N. (2020). Pengaruh Modal Psikologikal Terhadap Persepsi Iklim Keselamatan Kerja Yang Dimediasi Oleh Kepuasan Kerja Pada Tenaga Perawat RSUD Meuraxa Banda Aceh. Jurnal Ilmiah Mahasiswa Ekonomi Manajemen, 5(1), 38-51.

Maria, S., Wiyono, J., \& Candrawati, E. (2015). Kejadian Kecelakaan Kerja Perawat Berdasarkan Tindakan Tidak Aman. Jurnal Care, 3(2).

Oktavia, W.R., Nerawati, D., \& Sari, E. (2018). Penerapan Pelayanan Kesehatan Dan Keselamatan Kerja Pada Perawat IGD Rumah Sakit Umum Dr. Wahidin Sudiro Husodo Mojokerto Tahun 2017. Gema Kesehatan Lingkungan, 16(1).

Pitoyo, J., Hamarno, R., \& Sa'adah, T. E. (2017). Kepatuhan Perawat Menerapkan Pedoman Keselamatan Kerja Dan Kejadian Cedera Pada Perawat Instrumen Di Instalasi Bedah Sentral. Jurnal Pendidikan Kesehatan, 6(2), 65-70.

Putri, S., Santoso, \& Rahayu, E. P. (2018). Pelaksanaan Keselamatan Dan Kesehatan Kerja Terhadap Kejadian Kecelakaan Kerja Perawat Rumah Sakit. Jurnal Endurance, 3(2), 271277.

Salmawati, L., Sumarni, \& Soebijanto. (2015). Hubungan Penerapan Sistem Manajemen Keselamatan Dan Kesehatan Kerja Dengan Motivasi Kerja Dan Stres Kerja Pada Perawat Di Rumah Sakit Umum Anutapura Palu. Jurnal Manajemen Pelayanan Kesehatan, 18(1).

Salawati, L., Taufik, N. H., \& Putra, A. (2014). Analisis Tindakan Keselamatan Dan Kesehatan Kerja Perawat Dalam Pengendalian Infeksi Nosokomial Di Ruang ICU RSUD Dr. Zainoel Abidin Banda Aceh. Jurnal Kedokteran Syiah Kuala, 14(3).

Sitorus, E. D., \& Sunengsih, A. (2016). Tingkat Kepatuhan Perawat Mengenai SOP Dalam Penggunaan APD Di Ruang Rawat Bedah LT.12 Blok.D RSUD Koja Jakarta Utara Tahun 2016. Jurnal Akademik Keperawatan Husada Karya Jaya, 2(2). 
Simamora, R. H. (2020). Pelatihan Komunikasi Efektif untuk Meningkatkan Efikasi diri Perawat dalam Pelaksanaan Identifikasi Pasien. JURNAL ILMIAH KESEHATAN MASYARAKAT: Media Komunikasi Komunitas Kesehatan Masyarakat, 12(1), 49-54.

Simamora, R. H. (2011). ROLE CONFLICT OF NURSE RELATIONSHIP WITH PERFORMANCE IN THE EMERGENCY UNIT OF HOSPITALS RSD DR. SOEBANDI JEMBER. The Malaysian Journal of Nursing, 3(2), 23-32.

Suharto, \& Suminar, R. (2016). Hubungan Pengetahuan Dan Sikap Perawat Dengan Tindakan Pencegahan Infeksi Di Ruang ICU Rumah Sakit. Jurnal Riset Hesti Medan, 1(1).

Tukatman, Sulistiawati, Purwaningsih \& Nursalam. (2015). Analisis Keselamatan Dan Kesehatan Kerja Perawat Dalam Penanganan Pasien Di Rumah Sakit Benyamin Guluh Kabupaten Kolaka. Jurnal Ners, 10(2), 343-347. 